\title{
計量臨時量詞の構文機能 一空間様態描写機能を中心に一
}

\author{
加 納 希 美
}

(東京大学·院)

概要 臨時量詞は計量臨時量詞と計数臨時量詞の二類から成る。このう ち計量機能をもつ計量臨時量詞について、従来の研究は語やフレーズ単 位での文法的・意味的特徴を明らかにしてきた。しかし、計量臨時量詞 の構文単位における機能については未だ充分な知見が得られていない。 本稿では計量臨時量詞の空間性に着目することにより、移動・存在・授 与・結果を表す各構文中の機能として主に次の点を明らかにした。計量 臨時量詞は（I）有界化空間を表す要素として方位詞を伴う名詞句と機 能分担し、（II）特に存在空間の様態描写に寄与する。本稿はまた計量 臨時量詞独自の代替・指示機能を指摘し、その独自性が計量臨時量詞の 臨時性や名詞性に起因することを示した。本稿が指摘する計量臨時量詞 の空間性に基づく機能や代替機能との関連により、計量臨時量詞出現時 の談話環境や各構文中に現れる文法現象が計量臨時量詞に特有のもので あることを合理的に説明できる。

キーワード 臨時量詞 様態描写 トコロ化 一体化 代替性

\section{1. はじめに}

量詞カテゴリにおいて臨時量詞として区分される一類がある。臨時量詞 は名詞を借用して量詞とするものであり、次のように計量機能をもつ計量 臨時量詞と計数機能をもつ計数臨時量詞とに分けられる ${ }^{1)}$ 。表中の各フ レーズの二重下線の要素が臨時量詞である。

表 1 計量臨時量詞と計数臨時量詞

\begin{tabular}{|c|c|}
\hline 【計量臨時量詞】 & 【計数臨時量詞】 \\
\hline (1) a. 一桌子土 b. 一脚泥 & (2) a. 一碓饭 b. 一袋面 \\
\hline
\end{tabular}

両類の臨時量詞はいずれも数詞を伴い、後方の名詞性成分と共に (1a) “一桌子土”や、(2a) “一碗饭” 等のフレーズを構成できるが、次の 
点で異なる。朱德熙 1982: 50 に拠れば例えば(1a)は“满桌子土”の意味 となり、計量臨時量詞に伴う数詞は“一”に限定される。一方 (2a) は “满碗饭”の意味をもたず、計数臨時量詞に伴う “一”は “两”や “几” 等他の数詞とおき換え可能である。また計量臨時量詞の場合、例えば (1a) は“一桌子的土”のように“的”を挿入できるが、計数臨時量詞を含む (2a)は“的”を挿入できない。刘月华等 1983: 84 では、(1)の夕イプを量 詞としてではなく“一”に連用される名詞として記述し、これらは“儿 化”を起こさないのに対し、(2)のタイプの中には“一身儿衣服”のよう に“儿化”を起こすものがあるとしている。このように従来の研究の多く は、語やフレーズ単位での文法記述や意味記述に留まる。しかし上記の一 連の記述にも見られるように、二種類の臨時量詞のうち特に計量臨時量詞 は量詞としての特殊性を備えることから、フレーズょり上位の構造におい ても独自の機能を担っていると推測される。

計量臨時量詞は特定の名詞と固定的選択関係をもたず、主として事物の 量を表す。一方、特定の名詞と固定的選択関係をもつ専用量詞は、事物の 個体数を表す。この量と数という対極的な事物把握は、次の二例に示すよ うに動態、静態という事象タイプの対立に関与する等、様々な言語現象と して現れる。

(3) 我出了房间, 在走廊墙上摘了一架泡沫灭火机, 倒举着一路扫射冲出 走廊, 扔了灭火机下了楼。一楼人都跑光了, 扔了一地形形色色的 鞋。(王朔《永失我爱》)

(一階の人々は皆逃げ去っており、地面一面に色とりどりの靴が放ら れていた）

(4) 近日, 我出差在外, 在某市汽车站等车时随手扔了一根烟头, 被一戴 红袖套的老太太 “逮住”, (《人民日报》2002.01.09 第11 版 )

（ある町のバス停でバスを待っている時に、つい吸款を 1 本捨ててし まい)

計量臨時量詞 “地”を用いる (3) は、“鞋” が存在する空間の様態を運動 結果として静態的に描いている。一方専用量詞 “根”を用いる (4) は、行 為の実現を動態的に表しはするが、“烟头”の存在空間を描写してはいな い。量詞が現れる談話環境や構文的要因を排し、語やフレーズ単位での記 
述に留まる限り、叙述の動態性に対応する量詞選択の動機や、談話レベル での事象解釈の差は十分に説明し得ないであろう。

また、計量臨時量詞はしばしば次の (5)のように、判断詞 “是”を伴う 形式に現れる。

(5) 高花一脸都是麻子

刘顺 2003: 187 が (5) を「存現文の形式」として例示するように、“一脸” と“麻子” は存在関係を成し、“一脸” は “麻子”が存在する空間（存在 空間）として、また“麻子”はその空間に存在する事物（存在事物）とし て理解できる。しかし (5) は本来的に “是”により前後の二要素の同定関 係を表すものであり、“黑板上写了两个字（朱德熙 1982: 115）”のような 典型的存現文とは別種の存在認定を反映する形式である。計量臨時量詞は (5)のタイプの存在表現には適用できても、典型的存現文の形式には適用 できない（*高花一脸长了不少麻子）。コーパス中の実例においても典型的 存現文に計量臨時量詞を用いる例は見られず、これらの事実は (5)の形式 による存在関係が、典型的存現文の構文的意味特徴と合致しない特殊なも のであることを示唆している。しかし計量臨時量詞に関する従来の研究で は、存現文の構文的意味特徴との関連からこの問題が論じられることはな く、存現文の成立と計量臨時量詞との関連を説明し得る議論が尽くされて いるとは言い難い。

本稿では計量臨時量詞を $\mathrm{N}_{\mathrm{Q}}$ 、“一”を伴う $\mathrm{N}_{\mathrm{Q}}$ を yi $\mathrm{N}_{\mathrm{Q}}$ と記し、yi $\mathrm{N}_{\mathrm{Q}}$ が 現れる種々の構文の考察により、各構文において $\mathrm{yi} \mathrm{N}_{\mathrm{Q}}$ が一貫して事物と 一体化した空間を表し、空間を描写する談話環境や構文によくなじむこと を指摘する。併せて、この $\mathrm{N}_{\mathrm{Q}}$ の特性により、前述のものを含め、以下の 各章で取り上げる様々な問題が説明可能となることを示す。

第 2 章では yi $\mathrm{N}_{\mathrm{Q}}$ が場所名詞句（LN）に準ずる機能をもつことや、談話 の静態的局面に適性をもつこと等を指摘し、これにより移動や存在を表す 構文に現れる一連の文法現象を説明する。第 3 章では、yi $\mathrm{N}_{\mathrm{Q}}$ が他の量詞 には見られない独自の指示機能や代替機能を備えることを指摘する。同時 に、yi $\mathrm{N}_{\mathrm{Q}}$ の指示機能が LN としての意味機能の前提にあることを示し、yi $\mathrm{N}_{\mathrm{Q}}$ が指示機能をもつからこそ、これを用いる二つの類似した構文形式が 異なる構造として分析され得ることを説明する。なお以下では便宜上、 
“一桌子土”の “土”のように、yi $\mathrm{N}_{\mathrm{Q}}$ が示す空間における存在事物（Entity）をEによって記す。

\section{2. 計量臨時量詞のトコロ性と “一”のトコロ化機能}

一般にトコロ化とは、事物を表す名詞が場所名詞句（LN）として空間 を表す役割を担う際、“上” “里” 等の方位詞や “这儿” “那儿” 等の指示 詞を伴う現象を指す。本章では非対格移動文（2.1 節）や判断存在文（2.2 節）において yi $\mathrm{N}_{\mathrm{Q}}$ がこの種のトコロ化を経た LN に準ずる役割を担う一 方、LNとの相違点をもつことを指摘し、2.3節では、事物と一体化した 空間を表すという $\mathrm{yi} \mathrm{N}_{\mathrm{Q}}$ の特性が典型的存現文の成立を妨げることを示す。

\section{1. 非対格移動文におけるトコロ化}

yi $\mathrm{N}_{\mathrm{Q}}$ を用いる構文の一つに、次のような非対格性の移動表現がある。

(6) a. 茶汁泼散一地 b. 白薯土豆撒了一地 この種の表現では、移動事物とその到達先の空間との間に発生する何らか の存在関係が表される。以下ではこれを非対格移動文とよび、当該構文中 に現れる $\mathrm{N}_{\mathrm{Q}}$ の意味機能を考察する。(6)に示すように、この種の移動構 文では $\mathrm{yi} \mathrm{N}_{\mathrm{Q}}$ を述語後方の補語位置におき、移動主体を表す要素を述語の 前方におく。この移動主体は、到達空間における存在事物を兼ねる。本稿

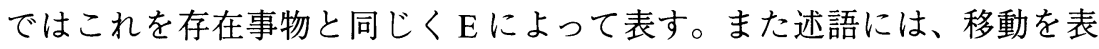
すと考え得る非対格性の動詞（“流”等）の他、他動詞性の動詞（“泼” 等）を用いることができる ${ }^{2)}$ 。

一般に非対格性の構文において他動詞性の述語を用いる際には、何らか の有標形式による非対格化が図られる。例えば、いわゆる自然被動文では 述語動詞が VR 構造をとる。また典型的受影文ではVR 構造を用いる他、 主語以外の位置に現れる動作主の要素が “被”によってマークされること が知られている（木村 2000: 19）。次の非対格移動文で VR 構造を適用し ナル的叙述を構成するのも、この種の構文の非対格性の現れである。

(7) 他被震耳的响声惊跳而起, 发觉自己的随从屈身伏在床前发出低沉的 呻吟。地上碎了一堆精白的瓷片, 浓绿的茶汁泼散一地。（廉声《月 色狰狞》)

（濃緑の茶汁が一面にぶちまけられていた） 
(8) 赵双环跑到电站。（略) 只见肖志君拿着一把活动扳手, 在拆卸碾米 机。丝帽、弹簧和半圆的篮片摆满一地。( 叶蔚林《蓝蓝的木兰溪》) (ナットにスプリング、それに半円の多孔板が床一面に並べられてい た）

上記二例に示すように、VRの R としてはしばしば “满/散”等が用いら れ、移動個体にとっての存在空間が VRによるナル的叙述の対象とされ る。しかし述語動詞が他動詞である場合に、常にVR 構造を構成するわけ ではない。

(9) 失魂落魄地跑回家, 大衣柜敞着门, 衣服推了一床。穗珠可能回娘家 去了，总之人去楼空。(张欣《掘金时代》)

（大きな洋服箪笥は扉が開いたままで、服がベッド一面に広げられて いた）

（9）は述語形式にVR 構造を用いておらず、一見非対格構文の原則に反 するようであるが、実際には “一床”の付加そのものが非対格化に寄与し ていると考えられる。なぜなら“一床”の “一”は “满”の意味を表すと される要素であり、“一床”は「ベッド一面が事物で満ちている」という 様態を表すため、VR 構造に準ずるナル的叙述として非対格構文の要求に 適い得るからである。“满 / 散”に限らずこの “一床”も、移動する事物 の様態ではなく空間の様態を表すが、いずれの場合もその背景には、移動 事物が個体性を欠き、空間と一体化することで、その空間が際立つという 談話状況がある。例えば、上記三例のコンテクストから判断する限り、傍 点部の述語動詞の運動は、話し手が視覚的に経験したことではない。この ため移動主体は、移動運動により顕著となるはずの個体としての際立ちを 欠き、静態的結果状況において空間様態の一部として把握され得る。この 存在空間の際立ちは、当該構文に $\mathrm{yi} \mathrm{N}_{\mathrm{Q}}$ が現れる際の顕著な特徵の一つで ある。

述語動詞が “落了一地”のようにアスペクト助詞“了”(-le) を伴い、 yi $\mathrm{N}_{\mathrm{Q}}$ を補語とする述補構造（V le + yi $\mathrm{N}_{\mathrm{Q}}$ ）を構成するとき、yi $\mathrm{N}_{\mathrm{Q}}$ は静態 と動態の両局面に対応し得る。次の (10) は静態的談話展開における適用 例である。

(10) 他们来到田里, 首先就发现了一个奇怪的事情 : 老柳树死了!（略） 
它的最后一片绿叶也干枯了, 折断的枝枒落了一地; (张炜《秋天的 愤怒》)

（最後の一片だった緑の葉も枯れてしまい、折れた小枝が一面に落 ちていた）

例文中の下線部は、田野の光景を描写する場面の一部である。ここでは、 述語動詞 “落” の運動そのものを実況的に述べ立てているのではではな く、静態的な結果状況を描写している。これに対し、次では運動を動態事 象として実況的に述べ立てている。

(11) 我把一个盛满红葡萄酒的瓶子倒篦在手里, 整瓶红酒冲盖而出, 洇湿 了雪白的桌布, 顺着我的胳膊肘流了一身, 祄衣裤子全染红了。（王 朔《动物凶猛》)

（私のひじを伝って全身に流れ、シャツやズボンがみな赤く染まっ た）

(12) 走几步把口袋放到地上歇一歇, 碰到电杆就把竹筐挤在上边喘口 气。恰好在距离有道他们不远的一棵电杆旁, 竹筐的背带断了, 白薯 土豆撒了一地…… (邓友梅《别了, 濑户内海! 》)

(竹かごのバンドが切れて、サッマイモやジャガイモが地面一面に 散らばった）

(13) “哗啦” 一倒, 花里胡哨的塑料玩具立马堆了一地。（陈建功《要 叉》)

（ガラッとひっくり返すと、すぐさま色とりどりのプラスチック製 の玩具が地面一面に積み上げられた）

例えば(11)では、話し手の眼前で展開する “红酒” の流動をその経路に 沿って描いている。下線部中に示す非対格移動文はその場面の一部であ り、“红酒”の運動を動態事象として表しているが、同時に、その補語位 置では、全身に液体が残留した状態を結果状態として表してもいる。この 結果表現という点において先の (10) と共通する。(10)ではナル的運動 “落”は実況性にそしく、ほとんど結果叙述のためたけけにこの形式を用い ていた。このことからも、当該の構文が結果表現によりなじむことが示さ れる。したがって、ちょうど VR 構造が〈(スル)・ナル〉型の複合的叙述 構造をもつ（Kimura 1997: 25）ように、この種の非対格移動文は、運動· 
結果から成る複合事象のうち、特に結果描写を本務とする〈ナル・アル〉 型の叙述構造をもつもの、と特徴付けられる。この叙述構造の配置は、重 要な情報を文のより後方におく中国語の大原則にも合致する。この〈ナ ル・アル〉型の叙述において、前半のナル的事象では移動事物がプロ ファイルされるが、後半のアル的事象ではプロファイルの対象が交替し、 描写対象としての到達空間の方が一層明確な際立ちを得る。この同一文内 でのプロファイル交替は、(11)(12)に見られるような述語形式、即ち “V le + yi $\mathrm{N}_{\mathrm{Q}}$ により支えられる。この形式は“了 (-le)”によって述語と 補語の位置を隔て、述補間の構造的断絶を類像的に反映している。この構 造的断絶によってこそ、この種のプロファイル交替は可能になるのであ る。次の表現も、この構造的断絶によって説明され得る。

(14) 那天我们走后, 她反锁在屋里, 用刀片切开了自己手腕的动脉血 管, 血流了一地, 没有遗书。(王朔《一半是火焰, 一半是海水》)

（血が床一面に流れていて、遺書は無かった） (14)のコンテクストに基づけば、下線部中の “流了”が表す運動は自害し た当事者以外確認し得ない状況で実現している。この運動は “一地”の様 態に基づき、現場発見者によって「推理」されたものにすぎず、そこに は、観察されなかった原因事象と観察された結果事象という二事象間の断 絶が存在する。この観察の断絶は二事象間の時間的断絶と共に、原因と結 果の断絶、運動と結果の断絶として、位置を分断する構造 “V le + yi $\mathrm{N}_{\mathrm{Q}}$ ” に反映される。ここにおいても、叙述事象と構造との間の極めて類像的な 対応関係を見て取ることができる。なお〈ナル・アル〉型の事象叙述で はプロファイル交替に伴い観察の断絶を伴うことになるが、これは (14) のような結果のみの観察という観察の断絶に通ずるものである。

(11) (12)のような動態事象叙述においても、なお結果状況に叙述の重点 がおかれ得る理由は、この断絶構造に求められた。この種の断絶構造は到 達空間における結果状況に情報的価值をおくための恰好の装置であり、当 該構造の補語位置は最も情報価値がおかれる結果状況叙述の場として用意 されているのである。この補語位置に $\mathrm{yi} \mathrm{N}_{\mathrm{Q}}$ が現れるということからも、 yi $\mathrm{N}_{\mathrm{Q}}$ の顕著な空間描写偏向を見て取ることができる。

ところで、次に挙げる移動表現では、場所名詞句（LN）として “地 
上”が用いられている。

(15)……被子掉到了地上。刘美萍轻轻把被子拣起来……(王朔《顽 主》)

(‥掛け布団が床の上に落ちた。刘美萍はそっと掛け布団を拾い上 げッ)

(16)……丈夫的一声吼, 使她浑身一哆嗦, 手里托着的衣裳便掉在了地上

$\cdots \cdot . .$. (刘心武《一窗灯火》)

(夫夫の怒声で全身がビクッと震え、手に持っていた服が床の上に 落ち $\cdots)$

これらは主語に無生の移動主体（E）をおき、且つ非対格性の述語形式 （VR）をもつ。両例における LN の位置は、ちょうど (11)-(14)の $\mathrm{yi} \mathrm{N}_{\mathrm{Q}}$ の位置に相当し、移動表現としての構文的意味からも、 $\mathrm{LN}$ と yi $\mathrm{N}_{\mathrm{Q}}$ は共 に到達空間を表すことが示唆される。しかし、LN と yi $\mathrm{N}_{\mathrm{Q}}$ は常に同じ条 件下で用いられるわけではない。例えばLNを含む(15) (16)では、VRの $\mathrm{R}$ に“到/在”等を用いているが、yi $\mathrm{N}_{\mathrm{Q}}$ を含む次の (17)にこれらを用い る表現は成立しない。

(17) 血流*在/*到了一地。

“满 / 散” 等と異なり、“到 / 在” は空間状態ではなく、移動事物側の変 化として移動過程での位置変更や到達空間への残存を表す。このことが $\mathrm{yi}$ $\mathrm{N}_{\mathrm{Q}}$ の空間描写偏向に反し、表現の成立を妨げるのである。非対格移動文 の補語位置に現れるこの種の制約を仮にVR 制約とよぶ。この現象につい ては 2.3 節において構文的意味との関連から更に分析を加えたい。

\section{2. 判断存在文におけるトコロ化}

前節での考察を通じ、yi $\mathrm{N}_{\mathrm{Q}}$ は移動表現において LN と類似の意味役割 を担い、また一方で、一部の移動表現において LN とは異なる制約を受け ることが分かった。本節では更に “是”を含む存在表現に反映される両者 の異同を分析する。

次の二例は、刘顺 2003: 188 において「存現文の形式」として例示され るものである。
(18) a. 高花一脸都是麻子。
b. 张三一身都是泥。

この種の存在表現を本稿では仮に判断存在文とし、“Xx + 都是 $+\mathrm{E} ” に$ 
よって表す。 $\underline{X}$ は全体-部分」の関係において $\mathrm{N}_{\mathrm{Q}}$ を「部分」とする際 の「全体」であり、ちょうど “他眼睛大大的”に代表される、いわゆる二 重主語文の第一主語と第二主語の関係に相当する。

一方、次の (19) は LNが $\mathrm{x}$ として現れたもの（X LN + 都是 $+\mathrm{E} ）$ と見 ることができる。

(19) 高花脸上都是麻子。

このことから、“文x + 都是 + E” は同じ $\mathrm{x}$ の位置に LN と yi $\mathrm{N}_{\mathrm{Q}}$ を等しく おくことのできる形式であることが分かる。なお、次のように身体部位名 詞が裸の形で $\mathrm{x}$ として現れるケースはまれである。特にこの場合、“头 发”と “蛇” から成る存在関係を表すというよりは、通常の判断文として “头发”と“蛇”との同定関係を表すと考えた方が自然であろう。

(20) 你看, 你看那个女人, 她头发都是蛇! (袁帅《色》)

（おい、あの女を見ろ、あいつの髪はみな蛇だ!）

上記のことから、身体部位名詞が判断存在文の $\mathrm{x}$ 位置に現れるには、何ら かの要素の付加を必要とすることが分かる。(18)のように身体部位名詞を $\mathrm{N}_{\mathrm{Q}}$ とする yi $\mathrm{N}_{\mathrm{Q}}$ がその $\mathrm{x}$ として現れ得るのだとすると、 $\mathrm{N}_{\mathrm{Q}}$ は “一（yi）” の付加により方位詞を含む LN と同等の資格を得ているということにな る。これは即ち、“一”がある種のトコロ化機能をもつことを意味する ${ }^{3)}$ 。 $\mathrm{N}_{\mathrm{Q}}$ が “一”の付加によりLN と似通った機能を担い得るのだと考えれば、 非対格移動文において yi $\mathrm{N}_{\mathrm{Q}}$ が到達空間を表し得ることも、これにより説 明できる。しかし、上述のように、 $\mathrm{LN}$ と $\mathrm{y} \mathrm{N}_{\mathrm{Q}}$ は時に異なる文法的ふる まいを見せ、例えば非対格移動文では yi $\mathrm{N}_{\mathrm{Q}}$ だけが VR 制約を受けた。LN と yi $\mathrm{N}_{\mathrm{Q}}$ の相違を探る手掛かりとして、非対格移動文と判断存在文とを比 較すると、前者は本来的に移動事物の状態変化を描くための構造をもつの に対し、後者は存在空間の状態描写に適する、というように両者は構文特 徵を異にする。この点を踏まえ、次節では更に典型的存現文における LN と yi $\mathrm{N}_{\mathrm{Q}}$ の適性を比較する。

\section{3. 存現文におけるトコロ化}

次の (21) は事物の出現を表す出現表現であり、主語位置にLNをおき、 目的語位置に数量詞を伴う不定名詞句をおく。この形式は存現文の典型と して広く知られるものである。本稿で存現文という場合にはこの形式をも 
つものを指し、これを“LN+V+E”と記す。

(21) a. 商店里到了一批货 b. 屋里飞进来一只蜜蜂（朱德熙 1982:114） 存現文の目的語位置の $\mathrm{E}$ が不定名詞句として数量詞を伴うのは、その構 文的意味特徵に因る。刘安春等 2004: 100 に拠れば、この数量詞を伴う $\mathrm{E}$ は談話における後継性が強い。これは即ち、Eがその動向や状態変化に関 心を集める事物であることを意味する。存現文は、この「主役」としての $\mathrm{E}$ の地位を確立すべくこれを際立てるための構造をもち、数量詞の付加に よりその個体性をことさらに明示するのである゙)。

存現文において、通常、身体部位名詞（“脸” “身”等）は(22)のよう に、“上”を伴って LN の位置に現れる。一方 (23) のように、“一”を伴う 場合、この表現は不成立となる。

(22) a. 高花脸上长了不少麻子 b. 他身上沾了好多泥
(23) a. *高花一脸长了不少麻子
b. *他一身沾了好多泥

存現文の目的語は、通常は数量詞を伴うという事実に示されるように、個 としての離散性や空間からの独立性をもつ事物を表す。“脸上”のような 通常の LN は、事物とは独立した純然たる空間を表すため、数量詞により 個体性を明示された事物にとっての存在空間としてふさわしい。故に、 LNを主語におく (22) は問題なく成立する。一方、yi $\mathrm{N}_{\mathrm{Q}}$ が表す空間にお いて、存在事物は個としての際立ちを欠き、空間と一体化した面的な広が りをもつ。加えて、yi $\mathrm{N}_{\mathrm{Q}}$ の “一” が “满” の意味をもつことを考え併せ てみると、yi $\mathrm{N}_{\mathrm{Q}}$ は客観的な純然たる空間を表す LN とは異なり、事物と 一体化して捉えなおされた（その意味において主観的な）空間を表出する ことに特化した形式であると言える。この点で、yi $\mathrm{N}_{\mathrm{Q}}$ は “满墙”のよう な “满”を伴う空間表現に近い。このように空間と一体化した面的な広が りをもつ事物は、そもそも個体数が問題にならないため、事物を「数え る」表現は、yi $\mathrm{N}_{\mathrm{Q}}$ とはなじまない。事物の前に “不少” 等の数量詞を用 いる (23) の不自然さの理由はここにあると考えられる。なお、“满墙”を 用いた “*满墙挂着许多张照片” は不成立となるが、この理由も “满墙” の空間特性との関連から同様に説明可能である。

yi $\mathrm{N}_{\mathrm{Q}}$ は、時に存現文とよく似た形式の主語位置に現れる。例えば “一 墙全挂着山水画儿” は $\mathrm{yi}_{\mathrm{Q}}$ として “一墙”を用いたものである。この文 
は不自然だと判断されることもあるが、趙金銘 1989: 26-27では成立可能 な例として挙げている。しかしこの場合、存在事物を表す “山水画儿” は、典型的存現文とは異なり数量詞を伴わない。また “挂”が “着”を伴 うことから、出現ではなく静態としての存在を表す表現であることが見て 取れる。この二点において、当該表現中の存在事物は典型的存現文のそれ とは異なり、個としての離散性や独立性を欠く。また、趙金銘 1989: 27 が 指摘するとおり、ここでの “全” は “一墙”を包括する。こうして存在空 間の範囲が指定されることにより、その空間は叙述におけるプロファイル の対象となる。このように、当該表現を構成する一連の要素は、談話にお ける空間描写偏向をもち事物と一体化した存在空間を表す、という $\mathrm{N}_{\mathrm{Q}}$ の 空間特性に合致する。この、事物の個体性を際立てない表現 “一墙全挂着 山水画儿”が成立するのであれば、それは、こうした一連の有標性に支え られることによる。

存在事物や移動事物への関心を反映するという存現文の構文特徴は、実 は、非対格移動文の構文特徵でもある。非対格移動文では主語に移動事物 を表す要素をおくが、一般に非対格性の構文では主語が表す事物をプロ ファイルし、当該事物の動向や状態変化をナル的叙述によって表すからで ある ${ }^{5}$ 。一方 2.1 節で考察したように、非対格移動文に $\mathrm{N}_{\mathrm{Q}}$ を用いる際、 その VR 構造の R として適性をもつのは “满/散”等であった。これら は、単に存在空間の様態を表すのではなく、より正確には事物と空間とか ら成る存在関係の様態を表す。その意味で存在空間と存在事物の様態は表 裏一体のものである。このことから、VR 構造の R “满/散” 等に限定 するという非対格移動文の VR 制約は、事物の様態を描写する構文特徴と $\mathrm{N}_{\mathrm{Q}}$ の空間描写偏向との両立を図ることに因る現象として捉えられよう。

一連の現象が示す $\mathrm{N}_{\mathrm{Q}}$ の偏向性は、 $\mathrm{N}_{\mathrm{Q}}$ の量詞としての機能に基づき、次 のように説明可能である。 $\mathrm{N}_{\mathrm{Q}}$ は、本来的に個体数を表すのではなく、事 物と一体化した存在空間を表すものであった。このとき、事物は不可算の

「量」として見做される。このため、(24a)の “烟头”のように、専用量 詞と固定的選択関係をもつ事物に対しても、これを空間と一体化した不可 算の「量」として表す場合には (24b)の “地”ように $\mathrm{N}_{\mathrm{Q}}$ が適用される。

(24) a. 一根烟头 $\Leftrightarrow$ b. 一地烟头 
(24a)において専用量詞 “根”を伴う “烟头”は、個としての輪郭を備え る事物として存在空間に対しても独立性をもつ。このような通常の存在関 係を地と図の関係に喻えると、存在空間は存在事物に対する地となる。し かし (24b)のように空間を満たす事物がその領域の様態の一部と見做され る場合、その事物は量的な顕著性をもちながらも、個としての輪郭を失う ことで、不可算的となり存在空間と一体化する。これにより地であった存 在空間は際立ちを増し、描写対象としての資格を得るのである。ここにお いて、 $\mathrm{N}_{\mathrm{Q}}$ の適用動機である、「空間と事物の一体化を伴う有徵的存在関係 の把握」を見て取ることができる゙ ${ }^{6}$ 。

\section{3. 計量臨時量詞の意味機能（指示と代替）}

ここまでに $\mathrm{N}_{\mathrm{Q}}$ について次の点を明らかにした。第一に、 $\mathrm{N}_{\mathrm{Q}}$ は非対格移 動文や判断存在文において LN の機能の一部を分担する。第二に、 $\mathrm{N}_{\mathrm{Q}}$ は 談話環境や構文的条件において存在事物が際立つ局面ではその使用が制限 され、逆に、存在空間の様態描写に適性をもつ。これらを踏まえ、本章 3.1 節では使役移動事象を表す構文を、3.2 節では結果様態を描写する構文 を取り上げ、似て非なる構造をもつ両構文中での $\mathrm{N}_{\mathrm{Q}}$ の役割を考察する。

\section{1. 使役移動文}

\subsection{1. 二重目的語構文と使役移動文}

次の (25) は $\mathrm{N}_{\mathrm{Q}}$ を用いる使役移動文の実例であり、(26) の授与表現と多 くの共通点をもつ。

(25) a. 砸了我一锅溅了我一身汤我说什么了? (王朔《无人喝采》)

（鍋を落として私を全身スープまみれにして、それで私は何か言っ た?)

b. ……他先泼你一身脏水, 把事非颠倒得让你成为他的同类…… (余 秋雨《小人》)

（ㄱそいつはまずおまえを体中污水まみれにし、是非を転倒してお まえをそいつの同類にし…)

(26) a. 赔他一本新的。 b. 问你一个问题。（朱德熙 1982:118）

量詞タイプの相違を除けば、(25) と (26)の述語形式は共に “ $\mathrm{V}+\underline{X}_{1}+$ 数量 $+\mathrm{X}_{2}$ ”のように表記できる。また、(26) の類の授与行為は動作主の意図に 
よる事物の位置変更を伴うことから、意味上、一種の使役移動文と見立て 得る。その場合、授与表現の各構成要素の意味役割は使役移動文における それと並行し、例えば (26a)の $X_{2}$ “新的” は移動事物、 $X_{1}$ “他” は到達空 間としての役割を担う。(26) は、通常二重目的語構文として分析される。 典型的二重目的語構文では、間接目的語に人称代名詞を用い、直接目的語 に数量詞を伴う不定名詞句を用いること（中川 1973: 19）、更に、述語動 詞の表す運動が動作主の意図によるものであること等が知られている。

(25) のタイプの使役移動文はこれらの特徴をもち合わせるため、本稿では この種の表現を $(26)$ と同じく二重目的語構造 $\left(\mathrm{VO}_{1} \mathrm{O}_{2}\right)$ をもつものと仮定 する。

\subsection{2. 間接目的語脱落形式}

この種の使役移動文は、しばしば次のように $\underline{X}_{1}$ が脱落した形をとる7)。

(27)……为了遮盖汗臭, 酒了 [ ] 一身科隆香水。(老舍《鼓书艺》)

(…汗の臭いを隐すために、オーデコロンを全身にふりかける。)

(28)……他走到灰烬上, 用力地扒着。他沾了 [ ] 一身灰土, 终于扒到

了: (张炜《海边的雪》)

(…彼は灰燼の上まで歩いてゆき、力いっぱい掘り返し、体中をほ こりだらけにして、ついに掘り当てた。）

(26) の場合、 $\underline{X}_{1}$ の脱落は $\mathrm{O}_{1}$ の脱落を意味するが、(27) (28) の $\underline{X}_{1}$ の脱落は $\mathrm{O}_{1}$ の脱落に相当しない。なぜならこの二例では “一身”が $\mathrm{O}_{1}$ に相当し、 到達空間としての意味役割を担うと考えられるためである。したがってこ の場合は到達空間 “一身”を「部分」とする際の「全体」要素が脱落して いるに過ぎず、(27) (28) は二重目的語構文に必要な要素を完備していると 考えてよい。補完形式と脱落形式の構造的平行性は、例えば (25a) や (27) がそれぞれ “汤溅了我一身” “科隆香水酒了［］一身”のように $\mathrm{X}_{2}$ を述 語動詞前方におく対応形式をもつという事実からも示される。

なお、yi $\mathrm{N}_{\mathrm{Q}}$ にとっての全体要素 $\mathrm{X}_{1}$ は他の構文において常に想定可能な 要素ではなく、たとえば“他背来了一书包书”のように「全体一部分」の 関係が特定されにくい場合には、 $\underline{X}_{1}$ が脱落しているとは見做せない ${ }^{8)}$ 。ま た、 $\underline{X}_{1}$ の脱落は常に起こり得るものではなく、実際の談話環境におい て、コンテクスト内での照応により $\underline{X}_{1}$ が特定可能である場合に限られ 
る。(27) (28)の “一身” のように身体部位名詞から成る yi $\mathrm{N}_{\mathrm{Q}}$ を用いる場 合、その全体要素 $\underline{X}_{1}$ としては動作主と同一人物を指す要素として “他” “自己” 等が想定されるため、これらは脱落形式と見做すことがで きる゙。

以上のことから、脱落形式はその形式や構文的意味において $\underline{x}_{1}$ が存在 する場合に等しく、(25)のような補完形式と同様に二重目的語構文の一種 として位置付けられる。

\subsection{3. 計量臨時量詞の指示と代替}

以上の考察を通じ、使役移動文や非対格移動文、判断存在文において、 yi $\mathrm{N}_{\mathrm{Q}}$ が LNに相当する意味役割を担い、事物にとっての存在空間を表す ことを見てきた。これは通常の量詞とは異なり $\mathrm{N}_{\mathrm{Q}}$ が名詞としての指示性 をもつことを前提とする。例えば非対格移動文 “茶汁泼散一地”において “地” は存在空間として “地”そのものを指す。次の (29) が不成立とな る理由も、同様に $\mathrm{yi} \mathrm{N}_{\mathrm{Q}}$ の指示性により説明可能である。

(29) *博物馆墙上挂满了唐代艺术品。一墙都很珍贵。

(29)の主語 “一墙”において “墙”が指す事物は、“珍贵”という様態の もち主 “艺术品”ではなく、“艺术品”の存在空間でしかないため、この 表現は不成立となるのである。

ところで、一般に数詞と量詞とが結合した数量詞の形式は代替性を持つ とされている ${ }^{10)}$ 。これは、名詞句を限定する数量詞が偏正構造全体を代替 することを指すものであり、例えば “一本”は “一本书”を代替し得る。 この種の代替性は計数臨時量詞にも観察される。

(30) 这两瓶葡萄酒, 一瓶特别香, 一瓶却有点儿甜。

この場合、“瓶”の内容物を形容する “甜 / 香”が述語におかれることか らも、“一瓶” は “一瓶葡萄酒”を代替しているのであって、容器として の “瓶”を表しているのではないことが分かる。ところが、計量臨時量詞 $\left(\mathrm{N}_{\mathrm{Q}}\right)$ の場合、“一墙” 等の数量詞の形式 $\left(\mathrm{yi} \mathrm{N} \mathrm{N}_{\mathrm{Q}}\right)$ は存在空間を指示する ものではあったが、(29)の不成立に示されたように、その空間に存在する 事物を表すことはできなかった。この点で、代替により内容物を表し得る 計数臨時量詞とは対照的である。 yi $\mathrm{N}_{\mathrm{Q}}$ が代替性をもつとすれば、それは 次のような場合である。 
(31) a. [身上 ]一身是汗。 b. [ ] 一身是汗。

(31b) は (31a)に相当する事象を表すことができるが、それは “一身”が、 場所名詞句としての役割と数量詞としての役割を兼ねることによる。これ は即ち、“一身”と、その「全体」に相当する “身上”との間で成立する 代替であると言ってよい。通常の数量詞による代替は、単位化の対象との 固定的選択関係に依拠するものと考えられるが、yi $\mathrm{N}_{\mathrm{Q}}$ はこの種の代替の 前提となる、単位化の対象との固定的選択関係をもたない。その一方で、 yi $\mathrm{N}_{\mathrm{Q}}$ の指示する空間が、その「全体」に相当する空間との間に分離不可 能な「全体-部分」の関係を成す場合には、yi $\mathrm{N}_{\mathrm{Q}}$ はこの関係に依拠するこ とにより、独自の代替を実現し得るのである。例えば、(27)の“酒了 [ ]一身科隆香水” の場合は、“一身” の全体要素として、“他”“自 己”等を想定することができたが、これも、“一身”とその全体要素との 分離不可能性に依拠した代替の事例として捉えることができよう。

ところでこの種の $\mathrm{VO}_{1} \mathrm{O}_{2}$ 構造に $\mathrm{N}_{\mathrm{Q}}$ が適合するという事実は、一見 $\mathrm{N}_{\mathrm{Q}}$ が存現文に馴染まないという事実に反する。なぜなら $\mathrm{VO}_{1} \mathrm{O}_{2}$ 構造は、次 の点で存現文と極めて類似する意味構造を含むからである。まず、 $\mathrm{O}_{2}$ は 典型的には数量詞を伴う不定名詞の形をとる。また $\mathrm{O}_{1}$ の指示対象は到達 空間として解釈可能であり、その空間における移動事物の出現はちょうど 存現文の表す事象の構図と合致する（古川 1997: 255）。しかし二重目的語 構文の真の情報価値は、所有権の変更を表すことにある。授与を移動と見 立てた場合には、到達空間の状態変化を表すことにこそ最たる情報価値が おかれる ${ }^{11)}$ 。したがって、存在空間の様態描写に適合するという $\mathrm{N}_{\mathrm{Q}}$ の特 性は、むしろ当該構造の構文的意味に符合すると言える。

\section{2. 動補構造}

使役移動文とは別に、次のように補語位置に “yi $\mathrm{N}_{\mathrm{Q}}+\mathrm{E} ”$ を用いる表現 がある。

(32) 一楼人都跑光了, 扔了一地形形色色的鞋。（第 1 章 (3) の一部を再 掲）

(33) 落了一地叶子。

これらは形式的に $\mathrm{VO}_{1} \mathrm{O}_{2}$ 構造の $\mathrm{O}_{1}$ 脱落形式に類似する。また述語動詞と $\mathrm{E}$ とが動目関係を成し、次のように $\mathrm{E}$ を述語前方におく対応形式をもつ点 
でも $\mathrm{VO}_{1} \mathrm{O}_{2}$ 構造に近い。

(32’) 形形色色的鞋扔了一地。(33’) 树叶落了一院子。

しかし、(32) (33)は“一地”の前に人称代名詞を補えない。また両例の述 語動詞の運動は結果の発生に対して意図性をもたない。したがってこの種 の構文は典型的 $\mathrm{VO}_{1} \mathrm{O}_{2}$ 構造とは見做し難く、むしろ “yi $\mathrm{N}_{\mathrm{Q}}+\mathrm{E}$ ”を補語位 置におくものとして説明され得る。

コンテクストに拠れば、(32)では、第 2 章で取り上げた一部の非対格移 動文と同様、述語動詞 “扔” の実現とその結果状況の確認までの間に明ら かな時間的断絶が存在する。話し手は “扔”の実現を視覚情報として確認 しておらず、この種の構文においても述語形式の断絶構造 “V le + yi $\mathrm{N}_{\mathrm{Q}}$ ” と、断絶的因果関係との類像的対応を見て取ることができる。したがっ て、“yi $\mathrm{N}_{\mathrm{Q}}+\mathrm{E} ”$ を補語位置におくこの種の構文もまた、原因事象と結果事 象のうち、特に結果としての存在空間の様態を叙述の中核に据えるもので あると言える。本稿では仮にこれを結果様態文とよぶ。結果様態文には、 次のようなものも含まれる。

(34) 我们都累坏了, 抽了一屋子烟熏得大家都泪汪汪的……。（王朔《玩 儿的就是心跳》)

（我々はみな疲れ切っていた。吸った夕バコで部屋中が煙だらけに なり、煙でいぶされてみな目に涙を溜め…)

(34) は述語動詞 “抽”とEに相当する “烟”が動目（VO）関係を成す点 で $\mathrm{VO}_{1} \mathrm{O}_{2}$ 構造に近い。但し、“抽” は移動を表さず、また $\mathrm{E}$ 前置する対 応形式をもたない。更に“一屋子”の前に人称代名詞を補えない。少なく ともこの三点において、 $\mathrm{VO}_{1} \mathrm{O}_{2}$ 構造の典型から外れる。更に注意すべき は、述語動詞 “抽” は他動詞であるにも関わらず、この場面では行為主体 の特定は不要であり、描写される結果状態 “一屋子烟” が必ずしも動作主 によって意図されていないという点である。なおこの際の描写対象は、出 現する事物 “烟”の状態ではなくあくまで存在空間の状態である。

次の場合は述語動詞と $\mathrm{E}$ とが項関係になく、 $\mathrm{VO}_{1} \mathrm{O}_{2}$ 構造としての分析 の余地が無い。

(35)……杨妈差点儿一头撞在金府门前的大槐树上, 吓了一身冷汗。（陈 建功等《皇城根》) 
（‥楊おばさんは危うく金府門の前の大きなエンジュの木に頭をぶ つけそうになり、驚いて全身冷や汗をかいた。）

(36) 小趋初来就掉入水渠。（略）燋小趋滚了一身泥浆, 冻得索索发抖, 很可怜它。(杨㖓《干校六记》)

（小趨はやって来て間も無い頃用水路にはまった。（略）小趨が転 がって体中泥だらけになり、凍えてブルブルと震えているのを見 て、大変気の毒に思った。）

“滚”は他動詞として “泥浆”を目的語に取ることもあるが、(36)の場合 “泥浆”は “滚” の動作対象ではあり得ず、“滚” は “小趋”を移動主体 とする非意図的運動であることが分かる。ここでの “滚”と “泥浆”は動 詞と目的語の項関係を成すのではなく、複合事象を叙述する述補構造の構 成要素として分析できる。

以上の結果様態文 (32)-(36) は原因行為の実現より結果状況の叙述に情 報的価值をおく。例えば(36)の場合、波線部に示すように事件（“掉入水 渠”）の発生は既に叙述済みである。“滚”の実現はこの事件に伴う事象と して充分予測可能であり、わざわざその実現を積極的に述べ立てる動機は 薄弱である。この場合、存在空間 “一身”をプロファイルし、新規成立し た結果としての存在関係 “一身泥浆”を描写することこそが叙述の主目的 である。通常、運動事象を述べ立てる場合には運動事物が際立ちを伴う。 一方、運動結果である様態の描写を叙述の中核に据える場合、運動の実現 は前提として背景化されねばならない。結果様態文はこの種の事象表現の 要請に適う構文的条件を備えており、重点情報を述語後方に集中させる装 置としての動補構造と、この位置にあって到達空間を際立てる $\mathrm{yi}_{\mathrm{Q}}$ との 協働により、実現事象の背景化及び、結果情報の前景化を巧みに実現して いるのである。

結果様態文に類似する動補構造をもつものとしては、更に次のような表 現が挙げられる。

(37) 于是, 从第二天起, 小林每天下午下班, 就坐在板鸭车后边卖鸭子 收款。(略) 回家一身鸭子味, 赶紧洗澡。(刘震云《一地鸡毛》) （家に帰ると全身アヒルの匂いまみれで、大急ぎで污れを落とし た） 
（38）别跑一胠土！（老舍《牛天赐传》)

（走って足中を泥だらけにしてはいけません！）

これらの述語動詞には、ナル的事象を表すものとスル的事象を表すものと があるが、いずれも“了”を伴わず、 $\mathrm{E}$ と項関係を成さない。また、補 語と共に〈スル /ナル・アル〉型の叙述構造を構成し、因果関係の定着 により複合性を失った、因果粘着型の恒常的、習慣的夕イプ事象を表す。 当該構造が「歇后语」 “香炉上打喷德——碰一鼻子灰” の後項に適用され るという事実は、この構造の特徵を象徵している。字義通りの解釈では、 “碰”は原因事象を表し、“一鼻子灰”は結果事象として存在関係を表 す。これがイディオムとして確立するには、この二事象間の因果関係の恒 常性や公共性を必要とする。その関係の自明性によってこそ、当該表現の 通常の運用において、“碰”の字義通りの運動は述べ立ての必然性を欠 く。その反面、この種の「歇后语」は、構成要素の意味の総和が必ずしも 構造的意味と一致しないというイデイオムとしての特徴を備えもつ。原因 事象の述べ立てを本務としない〈スル／ナル・アル〉型の構造が、この 種の公共的因果表現に適用される所以である。

\section{4. おわりに}

本稿では計量臨時量詞（ $\left.\mathrm{N}_{\mathrm{Q}}\right)$ を用いる種々の構文や談話の分析を通じ て、 $\mathrm{N}_{\mathrm{Q}}$ が場所名詞句（LN）に準ずる機能を担い、特に空間様態を描写す る静態的局面に適性をもつことを明らかにした。通常事物の量的認定は、 対象事物の個としての際立ちが捨象され存在空間が相対的際立ちを備える 状況下で実現する。事物量を表す $\mathrm{N}_{\mathrm{Q}}$ の空間描写偏向は、その際の存在空 間の際立ちによって説明可能であった。しかし存在空間が際立ちを獲得し 得る理由は、より直接的には $\mathrm{N}_{\mathrm{Q}}$ が “一”を伴うことに求められる。この “一”は “满”の意味をもつとされるが、ある空間が厳密な意味で満たさ れるためには当該空間の有界性を必要とするのであり、有界空間としての 輪郭をもつからこそ、その空間は際立ち、描写対象としての確たる資格を 得るのだと考えられる。 $\mathrm{N}_{\mathrm{Q}}$ は“一”の付加により一種のトコロ化を受け るものでもあったが、この “一”は、より正確には積載手段マーカーとも いうべき機能を担う。事物名詞は “一”の付加を受けてこそ、その事物が 
対象の事物を満載する有界空間であることを表明し得るのである。 $\mathrm{N}_{\mathrm{Q}}$ は また、自身の示す空間にとっての「全体」領域を代替することはあって も、一般の量詞のような計量対象の代替はできなかった。そして、その一 要因は、 $\mathrm{N}_{\mathrm{Q}}$ 独自の臨時性故に計量事物との固定的選択関係をもたないこ とに求められた。

このように、 $\mathrm{N}_{\mathrm{Q}}$ は量詞と場所名詞句の機能を併せもつが、本稿の考察 では、各構文において $\mathrm{N}_{\mathrm{Q}}$ の適用が独自に様々な制約を受けることも示さ れた。〈有界的〉な対象を〈モノ〉とし、〈無界的〉な対象を〈トコロ〉と するのが自然な捉え方である（池上 2000: 188）とすれば、 $\mathrm{N}_{\mathrm{Q}}$ 適用時の、 有界空間における無界事物の量的把握は有徵的存在認定の形態といってよ い。本稿はこの有徵的存在関係こそが、 $\mathrm{N}_{\mathrm{Q}}$ 適用に対する様々な制約の所 以であると考える。

〈注〉

1) 杜道流 2007: 75 は臨時量詞を二類に分け、計数・計量機能の相違を類別基準の一つ とする。更に( \pm 積載可 / \pm 統計手段 / \pm 多量)の三点から両類の特徵を記述して いる。

2) 例えば “我把他脸上的肉渣一一擦去, “怎么吃了一脸。”(王朔《浮出海面》)” “吃”のように、この種の構文の述語動詞が直接移動を表さない場合もある。

3) なお、形容詞句相当の形式が述語位置に現れる際には、しばしば “我脸都是肉肉 的”、“我照都是红的”のような形をとる。このとき「部分」要素としての身体部位名 詞は、“上”や“一”を伴わない。

4) 古川 1997: 241 では存現文における不定名詞句の際立ちを量詞の個体化機能との関 連から指摘し、この際立ちを地と図の関係における図として喻えている。

5) 他動詞述語をもつ非対格移動文はヴォイス体系においていわゆる自然被動文の一種 として位置付けられる。その自然被動文について木村 2000: 24 では「動作対象につい ての状況を述べる文、即ち対象がどうナルかを問題にする文」であるとしている。

6)この種の「無界化」を受ける事物は微細なもの、又は一般に不要物とされるもので あることが多い。事物の個体性が捨象され、量的把握を受ける一要因として興味深 い。

7) 実例や引用例中の [ ] は $\underline{X}_{1}$ 要素のスロットを示すものであり、本稿筆者の挿入 による。

8)これに対し、例えば “阳台”と“一地”とは分離不可能な「全体-部分」の関係で あり、“水酒了一地”は “水酒了阳台一地”に対する脱落形式として用いられ得る。 
9)なお (27’a)については、対応形式においてもコンテクスト内での照応により脱落要 素の特定が可能であり、補完形式 “科隆香水酒了 [他]一身” と等価の移動事象を表 し得る。

10）朱德熙 1982: 51 では “代替”、陆俭明 1988: 172 では “指代”と記している。

11）西村 2002: 303-304 では英語の二重目的語構造について、到達領域の状態変化に情 報価値がおかれることを指摘している。

\section{〈参考文献〉}

古川裕 1997. 「数量詞限定名詞句の認知文法一指示物の<顕著性 $>$ と名詞句の <有標 性 $>$ 一, 『大河内康憲教授退官記念 中国語学論文集』: 237-266 頁。 東京 : 東方書店。

池上嘉彦 2000.『「日本語論」への招待』。東京：講談社。

木村英樹 2000.「中国語ヴオイスの構造化とカテゴリ化」、『国語学』247：19-39 頁。 中川正之 1973. 「二重目的語文の直接目的語における数量限定語について」,『中国語 学』218:19-22 頁。

西村義樹 2002. 「換喻と文法現象」, 西村義樹編『シリーズ言語科学 2 認知言語学 I :

事象構造』: 285-311 頁。東京：東京大学出版会。

杜道流 2007.「计数和计量一兼论 “名量词” 的功能类别」,「语言研究」 2007 年第 1 期 :

77-80 页。

Kimura, Hideki. 1997. 漢語被動句的意義特徵及其結構上之反映」, 『Cahiers de Linguistique-Asie Orientale』Vol.26 No.1（1997）：21-35页。

刘安春. 张伯江 2004. 篇章中的无定名词主语句及相关句式」, 『Journal of Chinese

Language and Computing』Vol.14 No.2 (2004)：97-105页。

刘 顺 2003. 「现代汉语名词的多视角研究」。上海 : 学林出版社。

刘月华・潘文娱・故韧 1983.「实用现代汉语语法」。北京 : 外语教学与研究出版社。

陆俭明 1988. 现代汉语中数量词的作用」, 中国语文杂志社编「语法研究和探索 (四)」:

172-186 页。北京 : 北京大学出版社。

趙金銘 1989. 「现代汉语中 “满” 和 “一” 的不同分布及其语义特征」, 「中国語」1989 年 11 月号 : 26-29 頁。東京 : 大修館書店。

朱德熙 1982.「语法讲义」。北京 : 商务印书馆。

〈付記〉

本稿執筆にあたりご指導下さった木村英樹先生、調査にご協力下さったインフォマン トの皆様に心より感謝申し上げます。 


\title{
计量临时量词的句式功能 \\ 一试论其空间情态描写功能一
}

\author{
加 纳 希 美
}

(东京大学・院)

提要 临时量词分为计量临时量词与计数临时量词。关于计量临时量词以 往研究大部分只限于描述其在词和词组层次中的句法、语义特征, 对于其 在句式及篇章中的功能并没有充分考察。本文着眼于计量临时量词的空间 性, 考察这一类量词在描述移动 - 存在 - 给予 - 结果的这四种句式中所起 的作用, 主要阐明: (I) 计量临时量词作为表示有界领域的成分, 在功能 上与带有方位词的名词性成分分工; (II) 计量临时量词有助于描写存在空 间的情态。此外计量临时量词还具有独特的替代、指称功能, 此二功能分 别以这类量词固有的临时性和名词性为基础。本文并指出, 计量临时量词 的空间性及替代性可以合理解释适用此类量词的篇章特征以及在各种句式 中呈现的现象的特殊性。

关键词 临时量词 情态描写 空间化 一体化 代替性 